\title{
Assessment of Fodder Cowpea (Vigna unguiculata, Walp) Genotypes Selected for Forage Yield
}

\author{
A. S. M. Badawy \\ Forage Res. Sec., Crops Res. Inst., ARC, Egypt
}

\begin{abstract}
Ten Cowpea (Vigna unguiculate L. Walp) genotypes were evaluated for forage yield, forage characters during 2014 and 2015 summer growing seasons at Sakha Agricultural Research Station in Egypt, to evaluate cowpea genotypes selected for high green forage yield and yield components under this study. Experiments were arranged in a randomized completely block design with four replications. Data indicated that highly significant different for genotypes, significantly $(p<0.01)$ affected by year, cutting and genotypes. The highest significant green forage at the first cutting of the first year $(31.85 \mathrm{~kg} / \mathrm{plot})$. While the least significant green forage yield at the second cutting of the first year. The highest genotypes for green forage yield were 4, 5, 7, 8 and 9 in the first cutting at the first year, while the least genotypes for green forage yield were 1, 7 and 8 . Also, most genotypes for green forage yield at the first cutting were significantly higher than the second cutting except for genotypes 2, 3 and 8 at the second year. Also, dry forage yield for all genotypes in the first cutting of the first year $(3.622 \mathrm{~kg} / \mathrm{plot})$ were significantly higher than values at the second cutting of the first year $(2.748$ $\mathrm{kg} / \mathrm{plot}$ ). Genotypes 4, 5, 7 and 9 in dry forage yield were superiorities in the two years (3.566 and 3.55), (3.482 and 3.362 ), (3.45 and 3.362) and ( 3.47 and 3.35), respectively. In addition, results showed leaves/stem ratio at the first cutting in both seasons were significantly lower than those recorded for second cutting in both seasons ( 83.4 and 83.5 versus 86.2 and $86.1 \%$ ). Over cuttings, the highest significant at genotypes 5, 6 and 7 in the first year (90, 87 and $87.5 \%)$. While in the second year the highest significant at genotypes 1, 5, 9 and $10(89.9,90,87$ and $87.5 \%)$. Stem diameter was significantly reduced with progress of growth season from the first to the second cutting $(0.749$ and $0.620 \mathrm{~cm}$.). Genotype 2 was the least significant $(0.657 \mathrm{~cm}$.) over years and cutting. Also, branching/ plant was significantly increased with progress of growth from the first to the second cuttings (4.525 and 4.705). While the obtained values at the first season was significantly lower than those of the second season ( 4.8 and $.75 \mathrm{branch} / \mathrm{plant})$. Over the studied years and cuttings, genotype 4 was the highest ground cover by $5.638 \mathrm{branch}_{\text {plant }}^{-1}$. While less ground cover were genotypes 2 and 10 (4.219 and 4.182 branch/plant ${ }^{-1}$ ).
\end{abstract}

Key words: fodder cowpea, (Vigna unguiculata), green forage yield, dry forage yield, leaves/stem ratio, stem diameter and branches/plant.

\section{INTRODUCTION}

Cowpea (Vigna unguiculata, L. Walp) is one of the most important crops native to central Africa. It is an annual legume crop that thrives in warm conditions. In the summer season of Egypt, there is acute shortage of animal feed (Hathout, 1987). Cowpea grain contains $23.4 \%$ protein, $1.8 \%$ fat and $60.3 \%$ carbohydrates and is a rich source of calcium and iron (Gupta, 1998). Because of its high protein (about 25\%), vitamins and minerals content, cowpea plays an important role in both human and animal nutrition (Nielsen et al., 1997; Singh et al., 1997, Krasova-Wade et al., 2006 and Nwosu et al., 2013). Cowpea is generally consumed in many forms. The haulms are highly digestible and useful as fodder for livestock (Singh, 2007; Tarawali et al. 1997a and Tarawali et al. 1997b). So, cowpea forms excellent forage and it gives a heavy vegetative growth and covers the ground, so that, checks soil erosion. It fixes about 70-240 kg. ha ${ }^{-1}$ of nitrogen pear season through its root nodules and grows well in poor soils (Singh, et al. 2003 and Lesly, 2005). Cowpea produced the highest forage yields in sandy loam soils with proper irrigation regime (Ali et al. 2004). Also, because of its ability to tolerate drought, cowpea is well adapted to the semi- arid tropics
(Kamara et al., 2010, De Ronde and Spreeth, 2007). It is subsistence crop, often intercropped with sorghum, maize and pearl millet. (FAO, 2004). Resistant to some important diseases and pest has significantly increased the yield and cultivated area of cowpea, (Ehlers and Hall, 1996). So that, growing cowpea became one of the solutions to face the shortage of summer forage (Shereen ELNahrawy 2018), also found that genotype (G12) had the highest values for the total fresh yield $(25.8$ $\mathrm{kg} / \mathrm{plot})$ an d dry yield $(2.639 \mathrm{~kg} / \mathrm{plot})$, in addition she revealed that highly significant differences exist among the genotypes for most the studied traits (fresh, dry, stem diameter and No. of branches/plant). Identification of the recommended genotypes and actual breeding requirement of cowpea growers are essential for continuous genetic improvement of genotypes for high yield and tolerance to biotic and abiotic stresses, (Millawithanachchi, et al., 2015). So there is a need for new genotypes to fill forage gap in this period (Ayan et al. 2012). Genetic distances were observed between new genotypes and local cultivar which recommended using it in breeding program to develop cowpea productivity, also genotypes G1, G2 and G3 were found suitable for obtained higher fresh and dry fodder yields, the values for fresh and 
dry forage yields obtained from G1 which recorded 19.72 and $5.83 \mathrm{t} / \mathrm{fad}$ ) followed by G2 and G3. (Sultan et al. 2016).

The aim of this study was to evaluate cowpea genotypes selected for high green forage yield.

\section{MTERIALS AND METHODS}

The present study was conducted at Sakha Agricultural Research Farms, Field Crops Research Institute (FCRI) Agricultural Research Center (ARC), Egypt, during 2014 and 2015 seasons. Genotypes were selected from the local cultivar Balady.

First, selection was based on shape and color of grains namely G1 to G9 . After that, they were evaluated on green forage yield resulting on the best nine genotypes. The nine genotypes plus the base balady population were included in the experiment. A randomized completely block design (RCBD) with four replicates was used. Plot area was $\left(12.25 \mathrm{~m}^{2}\right)$. Each plot consisted of five rows $0.7 \mathrm{~m}$ apart and $3.5 \mathrm{~m}$ long. Seeds were hand drilled on top rows at the seeding rate $30 \mathrm{~kg} / \mathrm{fad} .150 \mathrm{~kg}$ super phosphate $\left(15.5 \% \mathrm{P}_{2} \mathrm{O}_{5}\right)$ was applied before sowing and 20 unit nitrogen fertilizer after every cutting.. Other recommended agricultural practices were applied. Two cuts were taken at every season. Sowing dates were $10^{\text {th }}$, May and $6^{\text {th }}$ May in 2014 and 2015 , respectively. The $1^{\text {st }}$ and $2^{\text {nd }}$ cuts were taken after 63 and 96 days from sowing at the first season while, 55 and 92 days from the sowing at the $2^{\text {nd }}$ Season, respectively. Data were recorded as following traits;

1-Green forage yield (kg.plot $\left.{ }^{-1}\right)$.

2-Dry forage yields (kg.plot $\left.{ }^{-1}\right)$.

3 -Stem diameter $(\mathrm{cm})$.

4- Number of branches.plants ${ }^{-1}$.

5-Leaves/stem ratio (dry base).

Statistical analysis

All data were statistically analyzed by the analysis of variance (ANOVA) using MSTAT-C
(1986). Analysis of variance for the data collected in each cutting per year as well as combined analysis over years and cuts was performed as described by Cochran and Cox (1957). Combined analysis over cuts and years was performed, when the assumption of homogeneity of error was not rejected. The splitsplit design was used for analyzed, while year in the main plot, cutting was in the sub-plot and the genotypes were in the sub- sub plots. Means were separated using Least Significant Difference (LSD) test at 0.05 and 0.01 levels probability.

\section{RESULTS AND DISCUSSION}

Ten genotypes of fodder cowpea were evaluated through two cuttings in each of the two years of this study. Table (1) illustrated the analysis of variance over years and cuttings for green and dry forage yields. Cowpea genotypes maintained constant green and dry forage yields across variable years. Meanwhile, forage yields significantly ( $p \geq 0.01$ ) varied between cuttings. Also, the rank or the magnitude of the obtained green and dry fodder yields significantly $(\mathrm{p} \geq 0.01)$ varied with variable cuttings in variable years. Genotypes expressed significantly $(\mathrm{p} \geq 0.01)$ different green and dry forages. While, cutting $\times$ genotypes interaction, and year $\times$ cutting $\times$ genotype interactions were significantly $(\mathrm{p} \geq 0.01)$ different. This might indicate variable yields at different cutting in different years. This results are in agreement with those revealed by Ayan et al. (2012).

Table (2-a) showed means of the interaction among year $\times$ cutting $\times$ genotype for green forage yield (kg/plot). The highest significant green forage yield expressed at the first cutting of the first year $(31.85 \mathrm{~kg} / \mathrm{plot})$. Whereas, the least significant green yield, recorded at that same year of the second cutting (23.99 kg/plot). That might explain the reason for cutting $\times$ year interaction.

Table 1: Analysis of variance for green and dry forage yields combined over years and cuttings.

\begin{tabular}{lccc}
\hline S.O.V. & d.f. & $\begin{array}{c}\text { Green forage yield } \\
\left(\mathbf{k g} \cdot \mathbf{p l o t} \mathbf{~}^{\mathbf{1}} \mathbf{)}\right.\end{array}$ & $\begin{array}{c}\text { Dry forage yield } \\
\left(\mathbf{k g} \cdot \mathbf{p l o t}^{\mathbf{1}} \mathbf{)}\right.\end{array}$ \\
\hline Years (Y) & 1 & $15.990^{\text {n.s }}$ & $0.006^{\text {n.s }}$ \\
\hline Rep / years & 6 & 11.579 & 0.325 \\
\hline Cutting $(\mathrm{C})$ & 1 & $711.577^{* *}$ & $10.477^{* *}$ \\
\hline $\mathrm{Y} \times \mathrm{C}$ & 1 & $530.639^{* *}$ & $5.193^{* *}$ \\
\hline Error & 6 & 5.201 & 0.209 \\
\hline Genotypes $(\mathrm{G})$ & 9 & $65.064^{* *}$ & $1.045^{* *}$ \\
\hline $\mathrm{Y} \times \mathrm{G}$ & 9 & $0.448^{\text {n.s }}$ & $0.035^{\text {n.s }}$ \\
\hline $\mathrm{C} \times \mathrm{G}$ & 9 & $26 . .790^{* *}$ & $0.958^{* *}$ \\
\hline $\mathrm{Y} \times \mathrm{C} \times \mathrm{G}$ & 9 & $15.887^{* *}$ & $0.955^{* *}$ \\
\hline Error & 108 & 2.380 & 0.129 \\
\hline$* *:$ Significant at $1 \%$ level probability. & & & \\
n.s: not significant. & & &
\end{tabular}


Table 2-a: Means of interaction among year $\times$ cutting $\times$ genotype for green forage yield $(\mathrm{kg} / \mathrm{plot})$.

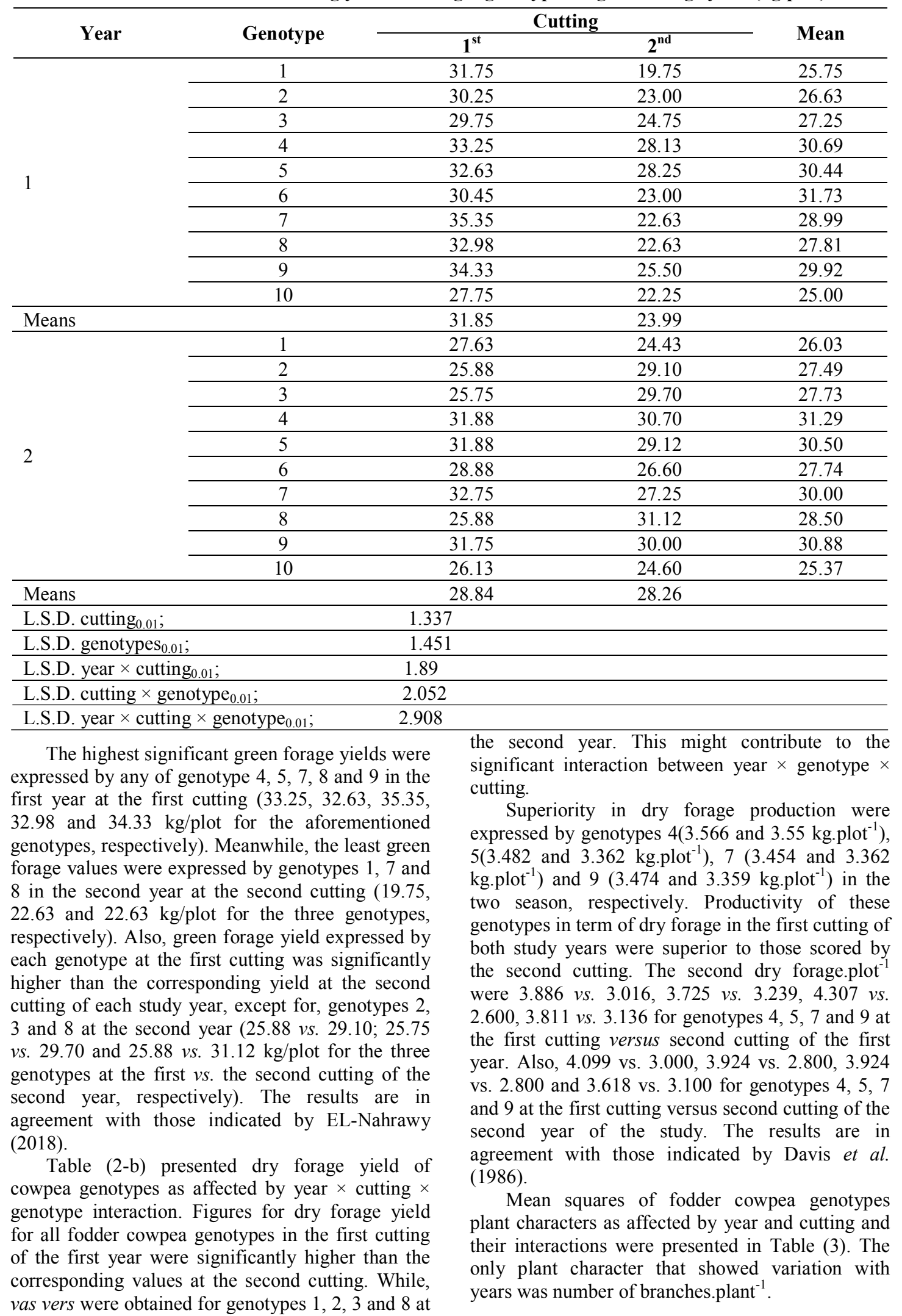


Table 2-b: Means of interaction among year $\times$ cutting $\times$ genotype for dry forage yield $(\mathrm{kg} / \mathrm{plot})$.

\begin{tabular}{|c|c|c|c|c|}
\hline \multirow{2}{*}{ Year } & \multirow{2}{*}{ Genotype } & \multicolumn{2}{|c|}{ Cutting } & \multirow{2}{*}{ Mean } \\
\hline & & $1^{\text {st }}$ & $2^{\text {nd }}$ & \\
\hline \multirow{10}{*}{1} & 1 & 3.470 & 2.403 & 2.937 \\
\hline & 2 & 3.488 & 2.617 & 3.053 \\
\hline & 3 & 3.366 & 2.686 & 3.026 \\
\hline & 4 & 3.886 & 3.016 & 3.566 \\
\hline & 5 & 3.725 & 3.239 & 3.482 \\
\hline & 6 & 3.442 & 2.508 & 2.975 \\
\hline & 7 & 4.307 & 2.600 & 3.454 \\
\hline & 8 & 3.743 & 2.557 & 3.15 \\
\hline & 9 & 3.811 & 3.136 & 3.474 \\
\hline & 10 & 2.985 & 2.185 & 2.735 \\
\hline Means & & 3.622 & 2.748 & \\
\hline \multirow{10}{*}{2} & 1 & 2.545 & 3.200 & 2.873 \\
\hline & 2 & 2.570 & 3.550 & 3.06 \\
\hline & 3 & 2.633 & 3.650 & 3.142 \\
\hline & 4 & 4.099 & 3.000 & 3.55 \\
\hline & 5 & 3.924 & 2.800 & 3.362 \\
\hline & 6 & 3.408 & 2.570 & 2.989 \\
\hline & 7 & 3.924 & 2.800 & 3.362 \\
\hline & 8 & 2.826 & 3.480 & 3.153 \\
\hline & 9 & 3.618 & 3.100 & 3.359 \\
\hline & 10 & 2.949 & 2.830 & 2.89 \\
\hline \multicolumn{2}{|l|}{ Means } & 3.250 & 3.116 & \\
\hline \multicolumn{2}{|l|}{ Mean of cutting } & 3.436 & 2.932 & \\
\hline \multicolumn{2}{|l|}{ L.S.D cutting $\cdot 0.01$} & 0.268 & & \\
\hline \multicolumn{2}{|l|}{ L.S.D genotypes. 0.01} & 0.338 & & \\
\hline \multicolumn{2}{|c|}{ L.S.D year $\times$ cutting .0 .01} & 0.379 & & \\
\hline \multicolumn{2}{|c|}{ L.S.D cutting $\times$ genotypes ${ }_{0.01}$} & 0.478 & & \\
\hline \multicolumn{2}{|c|}{ L.S.D year $x$ cutting $\times$ genotypes ${ }_{0.01}$} & 0.676 & & \\
\hline
\end{tabular}

Table 3: Analysis of variance for plant characters of fodder Cowpea genotypes as affected by year and cutting.

\begin{tabular}{lcccc}
\hline S.O.V. & d.f. & $\begin{array}{c}\text { Dry } \\
\text { leaves/stem ratio }\end{array}$ & Stem diameter & $\begin{array}{c}\text { No. of } \\
\text { branches.plant }\end{array}$ \\
\hline Years (Y) & 1 & $0.000^{\text {n.s }}$ & $0.110^{\text {n.s }}$ & $2.814^{* *}$ \\
\hline Rep / years & 6 & 4.5 & 0.02 & 0.234 \\
\hline Cutting (C) & 1 & $291.600^{*}$ & $0.676^{* *}$ & $1.229^{*}$ \\
\hline Y $\times$ C & 1 & $0.400^{\text {n.s }}$ & $0.036^{\text {n.s }}$ & $3.487^{* *}$ \\
\hline Error & 6 & 8.983 & 0.011 & 0.144 \\
\hline Genotypes (G) & 9 & $214.997^{* *}$ & $0.014^{*}$ & $3.383^{* *}$ \\
\hline Y $\times$ G & 9 & $30.264^{* *}$ & $0.005^{\text {n.s }}$ & $0.293^{\text {n.s }}$ \\
\hline C $\times$ G & 9 & $51.975^{* *}$ & $0.009^{\text {n.s }}$ & $1.109^{* *}$ \\
\hline Y $\times$ C $\times$ G & 9 & $54.442^{* *}$ & $0.008^{\text {n.s }}$ & $0.265^{\text {n.s }}$ \\
\hline Error & 108 & $8.177^{*}$ & 0.006 & 0.234 \\
\hline
\end{tabular}

Significant at5\% level probability.

** Significant at $1 \%$ level probability.

n.s.: not significantly different.

All three plant characters significantly varied with cutting and genotypes. The interaction between year and cutting showed significant variation only for number of branches.plant ${ }^{-1}$. Genotypes significantly varied in all plant characters.
Genotypes $\times$ year interaction was only significant for dry leaves/stem ratio. Meanwhile, cutting $\times$ genotypes interaction expressed significant variations in dry leaves/stem ratio and number of branches.plant ${ }^{-1}$. The second order interaction 
among year $\times$ cutting $\times$ genotype was only significant for dry leaves stem ratio. It was variable to notice that, stem diameter was not affected by any of years or year $\times$ cutting, year $\times$ genotype, cutting $\times$ genotype and year $\times$ cutting $\times$ genotype interaction.

Means of leaves/stem ratio (dry base) for fodder cowpea genotypes as affected by year $\times$ cutting $\times$ genotype interaction were presented in (Table 4). Overall fodder cowpea genotypes, leaves/stem ratio at the first cutting of the both study seasons were significantly lower than those recorded for second cutting $(83.4,83.5$ vs. 86.2, 86.1 percent for first cutting at both seasons versus the second cutting at both seasons). Over cuttings, the highest significant leafiness were those presented by genotypes 5,6 and 7 in the first year $(90.0,87.0$ and 87.5 percent for the three genotypes, respectively). Meanwhile, the highest significant leafiness were presented by genotypes 1, 5, 9 and 10 in the second year (89.9, $90.0,87.0$ and 87.5 percent for the previously mentioned genotypes, respectively). Leaves/stem ratio (dry base) of the studied fodder cowpea genotypes presented variable magnitude and/or trend with variable cutting. This might explain the reasons for year $\times$ cutting $\times$ genotypes significant interaction. The results are in agreement with those showed by (Magashi et al. 2014) and (Sultan and Salem 2016).

Stem diameter which stand for softness of forage tissue and easiness of chewing and swallow ness for fodder cowpea genotypes as affected by year $\times$ cutting $\times$ genotype interaction were presented in (Table 5). Stem diameter was significantly reduced with progress of growth season from the first to the second cutting $(0.749$ and $0.620 \mathrm{~cm}$ for the first and the second cuttings, respectively). Over years and cutting, fodder cowpea genotype number 2 , presented the least significant stem diameter $(0.657 \mathrm{~cm})$, whereas, the other studied genotypes had significantly higher stem diameter ranged between 0.644 and $0.719 \mathrm{~cm}$. These results are in agreement with those (Sharawy and EL-Fiky, 2003).

Ground indicated by the number of branches of fodder cowpea genotypes as affected by year $x$ cutting $\times$ genotype interaction were shown in (Table 6). Overall years, cuttings and genotypes, branching was significantly increased with progress of growth from first to second cutting (4.525 and 4.705 branch.plant ${ }^{-1}$ for the first and the second cuttings, respectively).

Table 4: Means of the interaction among year $\times$ cutting $\times$ genotype for Leaves $/$ stem ratio(dry base) for cowpea.

\begin{tabular}{|c|c|c|c|c|}
\hline \multirow{2}{*}{ Year } & \multirow{2}{*}{ Genotype } & \multicolumn{2}{|c|}{ Cutting } & \multirow{2}{*}{ Mean } \\
\hline & & $1^{\text {st }}$ & $2^{\text {nd }}$ & \\
\hline \multirow{10}{*}{1} & 1 & 85 & 87 & 86.0 \\
\hline & 2 & 80 & 83 & 81.5 \\
\hline & 3 & 81 & 84 & 82.5 \\
\hline & 4 & 79 & 83 & 81.0 \\
\hline & 5 & 88 & 92 & 90.0 \\
\hline & 6 & 86 & 88 & 87.0 \\
\hline & 7 & 87 & 88 & 87.5 \\
\hline & 8 & 78 & 80 & 79.0 \\
\hline & 9 & 84 & 87 & 85.5 \\
\hline & 10 & 86 & 90 & 88.0 \\
\hline Means & & 83.4 & 86.2 & \\
\hline \multirow{10}{*}{2} & 1 & 86.5 & 93.3 & 89.9 \\
\hline & 2 & 77 & 90 & 83.5 \\
\hline & 3 & 77.5 & 93.3 & 85.4 \\
\hline & 4 & 80 & 83 & 81.5 \\
\hline & 5 & 92 & 88 & 90.0 \\
\hline & 6 & 85 & 81 & 83.0 \\
\hline & 7 & 83 & 85 & 84.0 \\
\hline & 8 & 77 & 75 & 76.0 \\
\hline & 9 & 87 & 87 & 87.0 \\
\hline & 10 & 90 & 85 & 87.5 \\
\hline Means & & 83.5 & 86.1 & \\
\hline Over all mean & & 83.45 & 86.16 & \\
\hline L.S.D. cutting $0_{0.05}$ & & 1.16 & & \\
\hline L.S.D. genotype $\mathrm{e}_{0.01}$ & & 2.689 & & \\
\hline \multicolumn{5}{|c|}{ L.S.D. year $\times$ genotype ${ }_{\text {and }}$ cutting $\times$ genotype $_{(0.01)} 3.803$} \\
\hline L.S.D. year $\times$ cutting & notype $_{0.01}$ & 5.379 & & \\
\hline
\end{tabular}


Table 5: Means of the interaction among year $\times$ cutting $\times$ genotype in stem diameter $(\mathrm{cm})$ for fodder cowpea genotypes.

\begin{tabular}{|c|c|c|c|c|}
\hline \multirow{2}{*}{ Year } & \multirow{2}{*}{ Genotype } & \multicolumn{2}{|c|}{ Cutting } & \multirow{2}{*}{ Mean } \\
\hline & & $1^{\text {st }}$ & $2^{\text {nd }}$ & \\
\hline \multirow{10}{*}{1} & 1 & 0.725 & 0.575 & 0.650 \\
\hline & 2 & 0.700 & 0.525 & 0.613 \\
\hline & 3 & 0.675 & 0.600 & 0.638 \\
\hline & 4 & 0.750 & 0.650 & 0.700 \\
\hline & 5 & 0.725 & 0.625 & 0.675 \\
\hline & 6 & 0.700 & 0.625 & 0.663 \\
\hline & 7 & 0.675 & 0.675 & 0.675 \\
\hline & 8 & 0.650 & 0.600 & 0.625 \\
\hline & 9 & 0.775 & 0.600 & 0.688 \\
\hline & 10 & 0.700 & 0.600 & 0.650 \\
\hline Means & & 0.708 & 0.610 & \\
\hline \multirow{10}{*}{ 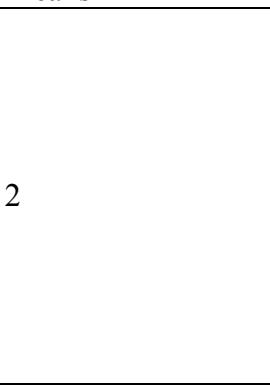 } & 1 & 0.725 & 0.650 & 0.688 \\
\hline & 2 & 0.825 & 0.575 & 0.700 \\
\hline & 3 & 0.775 & 0.675 & 0.725 \\
\hline & 4 & 0.825 & 0.625 & 0.725 \\
\hline & 5 & 0.850 & 0.675 & 0.763 \\
\hline & 6 & 0.775 & 0.600 & 0.688 \\
\hline & 7 & 0.775 & 0.700 & 0.738 \\
\hline & 8 & 0.800 & 0.550 & 0.675 \\
\hline & 9 & 0.800 & 0.725 & 0.763 \\
\hline & 10 & 0.750 & 0.525 & 0.638 \\
\hline Means & & 0.790 & 0.630 & \\
\hline Over all mean & & 0.749 & 0.620 & \\
\hline L.S.D. cutting ${ }_{0.01}$ & & 0.062 & & \\
\hline L.S.D. genotype $_{0.05} ;$ & & 0.055 & & \\
\hline
\end{tabular}

Table 6: Means of the interaction among year $\times$ cutting $\times$ genotype in No. of branches/plant for cowpea.

\begin{tabular}{|c|c|c|c|c|}
\hline \multirow{2}{*}{ Year } & \multirow{2}{*}{ Genotype } & \multicolumn{2}{|c|}{ Cutting } & \multirow{2}{*}{ Mean } \\
\hline & & $1^{\text {st }}$ & $2^{\text {nd }}$ & \\
\hline \multirow{10}{*}{1} & 1 & 4.500 & 5.700 & 5.100 \\
\hline & 2 & 3.875 & 4.175 & 4.025 \\
\hline & 3 & 4.125 & 4.725 & 4.425 \\
\hline & 4 & 5.000 & 6.125 & 5.563 \\
\hline & 5 & 4.625 & 4.125 & 4.375 \\
\hline & 6 & 4.000 & 3.525 & 3.763 \\
\hline & 7 & 3.500 & 5.050 & 4.275 \\
\hline & 8 & 4.500 & 4.800 & 4.650 \\
\hline & 9 & 4.570 & 4.575 & 4.573 \\
\hline & 10 & 3.750 & 4.350 & 4.050 \\
\hline Means & & 4.240 & 4.720 & 4.48 \\
\hline \multirow{10}{*}{ 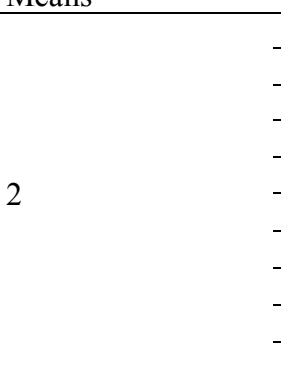 } & 1 & 5.075 & 4.500 & 4.788 \\
\hline & 2 & 4.475 & 4.350 & 4.413 \\
\hline & 3 & 4.625 & 4.825 & 4.725 \\
\hline & 4 & 5.375 & 6.050 & 5.713 \\
\hline & 5 & 5.125 & 4.650 & 4.888 \\
\hline & 6 & 4.500 & 3.925 & 4.213 \\
\hline & 7 & 4.650 & 5.225 & 4.938 \\
\hline & 8 & 5.000 & 4.525 & 4.763 \\
\hline & 9 & 4.850 & 4.550 & 4.700 \\
\hline & 10 & 4.375 & 4.250 & 4.313 \\
\hline Means & & 4.810 & 4.690 & 4.75 \\
\hline \multicolumn{2}{|l|}{ Over all mean } & 4.525 & 4.705 & \\
\hline \multicolumn{2}{|l|}{ L.S.D. years ${ }_{0.01}$} & 0.284 & & \\
\hline \multicolumn{2}{|l|}{ L.S.D. cutting } & 0.147 & & \\
\hline \multicolumn{2}{|c|}{ L.S.D. genotype } & 0.455 & & \\
\hline \multicolumn{2}{|c|}{ L.S.D. years x cutting x genotype $e_{0.01}$} & 0.643 & & \\
\hline
\end{tabular}


Meanwhile, the obtained values at the first season was significantly lower than those of the second season (4.48 and 4.75 branch.plant ${ }^{-1}$ for the first and the second season, respectively). Over the studied years and cuttings, genotype 4, enjoyed the highest ground cover expressed by 5.638 branch.plant $^{-1}$. Meanwhile, .less ground cover were presented by genotypes 2 and 10 (4.219 and 4.182 branch.plant $^{-1}$, respectively). The results are in agreement with (Gad EL-Hak et al. 1988).

\section{CONCLUSION}

Genotypes (4, 5, 7 and 9) were the superiorities in this study, so we can use its in the breeding programme to high forage yield.

\section{REFERENCES}

A BIOTICH. (2002). Cowpea (vigna unguiculate) and crop genetic transformation in general. Bulletin information. No. 07, July, 2002: 1-4. Alger. (also, availale at www.aab.org.dz).

Ajeigbe, H. A., Ihedioha, D., and Chickoye, D. (2008). Variations in Physicochemical Properties of Seed of Biotechnology Vol. 7(20), pp. 3639-3644.

Abadassi, J. (2015). "Cowpea (Vigna unguiculate (L.) Walp) agronomic traits needed in tropical zone " International Journal of Pure \& Applied Bioscience, 3, (4); 158-165.

Ali, Y. Z. Aslam, F. Hussain, A. Shakur (2004). Genotypes and environmental interaction in cowpea (Vigna unguiculata L.) for yield and disease resistance. Int. Environ. Sci. \&Tech. 1:119.

Ayan, I., M. Hanfie, B. Ugur, A. Zeki and O. O. Asci (2012). Forage potential of cowpea (Vigna unguiculata L. walp). Turkish J. of field crops. 17(2): 135-138.

Cochran, W. G. and G. M. Cox. (1957). Experimental Designs, John Wiley \& Sons, INC. N. Y., USA.

Davis, D. W., D. B. Marsh and M. N. Alvarez (1986). M N 13 and M N 150 cowpea breeding lines. Hort. Sci. 2 (4): 1080-1081.

De Ronde, J. A., M. H. Speeth (2007). Development and evaluation of drought resistant mutant germ-plasm of (Vigna unguiculata). Water, SA: 33 381-386.

Ehlers, J.D. and A. E. Hall (1996). Genotypic classification of cowpea on responses to heat and photoperiod. Crop Sci. 36: 673-679.

EL-Nahrawy, M. Shereen (2018). Agromorphological and Genetic Parameters of some Cowpea Genotypes. Alex. Sc. Exch. J. 39 (1): $56-64$.
FAO (2004). The State of Food and Agriculture 2003-2004: Agricultural BiotechnologyMeeting the Needs of the Poor? Food and Agriculture Organization of the United Nations. Rome, Italy.

Gad EL-Hak S., H. Mahmoud and R. A. Ragob (1988). An evaluation study of twenty four genotypes of cowpea (Vigna unguiculata (L.) walp). Minia J. Agric. Res. And Dev. 10 (1): 257-268

Gupta, Y. P. (1998). Pulse Crops.in: Nutritive value of pulses, Ed., B. Baldev, 5. Ramanujam and H. K. Jain, pp. 563.

Hathout, M. K. (1987). Production and management of dairy cattle in Egypt. Egyptian Holland Workshop, Animal Production Res. Inst., March, 30-31. Cairo, Egypt.

Hall, A. E., Singh, B. B., and Ehlers, I. D. (1997). "Cowpea breeding". Plant breeding Reviews, vol. 15, pp. 215-274.

Hall A.E., Cisse N., thiaw s. Elawad H.O. A., Ehlers J. D., (2003). Development of cowpea cultivars and germplasm by the Bean/Cowpea CRSP. Field Crops Research 82: 103-134.

Johanson, H.W., Robinson, H. and Comstock, R. F. (1995). Estimates of Genetic and Environmental variability on Soybean. Agronomy Journal, 47: 314-318.

Kravova-Wade T., O. Drouf T. Ndaye, C.E. Sail, S. B. Raconnier and M. Neyra, (2006). Watercondation effects on rhizobia competition for cowpea nodule occupancy. Afri. J. Biotech. 5; 1457-1463.

Kamara, A. Y., E-Jones and F Ekeleme. (2010). A participatory evaluation of improved cowpea cultivars in the Guinea and Sudan savanna zones of north east Nigeria. Archives of Agronomy and Soil Science, 56 (3); 355-370.

Lie, D. C., Fatokun CA., Ubi B, Singh BB, Scoles GI (2001). Determining Genetic similarity and relationships among cowpea breeding lines and cultivars by micro satellite markers. Crop Sci., 41: 189-197.

Lesly, D. W, (2005). Characterization and evaluation of cowpea (Vigna unguiculate (L.) Walp) germplasm. Msc of agriculture and plant breeding, Uni. Of agr. Sci. Dharwad58000. India.

Magashi A. I., S. F. Musa and I. Muhammed (2014). Evaluation of cowpea genotypes (Vigna unguiculata (L.) walp) for some yield and root parameters and their usage in breeding programme for drought tolerance. Int. J. of Advances in Agricultural and Environmental Eng., 1: 34-37.

MSTAT-C (1086). A microcomputer Program for the Design and Analysis of Agronomic Research Experiments. Michigan State Univ., USA. 
McGregor, S.E. (1976). Insect pollination of cultivated crop plants USDA.

Millawithanachchi, M. C; V. A.Sumanasinghe, A. P; Bentota and S. de z. Abeysiriwardena (2015). Performance of Different Breeding Methods in Cowpea (Vigna unguiculate, Walp) Improvement Programmes. Tropical Agricultural Research vol. (2): 294-302.

Nielsen S.S., T.A. Ohler, C.A. Mitchell (1997). Cowpea leaves for human consumption: production, utilization and nutrient composition. In: B.B. Singh, D. R. Moham Raj, K. E. Dashiell, Jackai (eds) Advances in Cowpea Research. Co-publication of International Institute of Tropical Agricultural Science (JIRCAS), IITA, Ibdan, Nigeria; 326-332.

Noubissie, J. T., Youmbi E. Njintong, N. Y., Alladoum, A. N., Nguimbou, M. R., and Bell., J. M. (2011). Genetic architecture of some leaf yield and quality attributes in dualpurpose cowpea (vigna unguiculate (L.) Walp) American Journal of Experimental Agriculture, vol. 1, no. 4, pp. 400-413.

Nwosu D. J., B. D. Olatunbosun, I. S. Adetiloye (2013). Genetic Variability, Heritability and Genetic Advance in Cowpea Genotypes in two Agro-ecological Environments. Greener J. of Biological Sci. 3 (5), 202-207.

Sharawy Wafaa. M. and Z. A. EL-Fiky (2003). Characterization of cowpea (Vigna unguiculata (L.) walp) genotypes based on yield traits and RAPD-PCR analysis Arab J. Biotech. 6 (1): 67-78.
Singh BB, Cambliss OL, Sharma B, (1997). Recent advances in cowpea breeding. In: B. B. Singh, D. R. Mohan Raj, K. Dashiell, L. E. N. Jackai (Eds) Advances in Cowpea Research. Co-publication of International Institute of Tropical Agriculture (IITA) and Japan International Center for Agricultural Sciences (JIRCSA), IITA, Ibadan, Nigeria, 30-49.

Singh BB, Ajejbe HA, Tarawali SA, FernandezRivera S, Abubakar M (2003). Improving the production and utilization of cowpea as food and fodder. Field Crops Res., 84 (1-2): 169177.

Singh, B.B. (2007). Recent Progress in Cowpea Genetics and Breeding. Proceedings of $1^{\text {st }}$ International Conference on Indigenous Vegetables and Legumes. M. L. Chadha (ed); 69-75.

Sultan Fadia N., Azza Khalil and S. Salem (2016). Evaluation of some cowpea genotypes in Egypt for growth yield and quality traits. Egyptian J. of Plant Breed. 20 (4): 593-608.

Tarawali S.A.; B.B.; Singh S.; Fernandez Rivera P, M; Smith J.W. Schutze-Kraft and R. Ajejgbe (1997 a). Optimizing the contribution of cowpea to food and fodder production in crop-Livestock systems in West Africa. Proceedings of the International Grassland Congress. Canada, 53-54.

Tarawali SA, B.B., Singh P. M Blade (1997 b). Cowpea haulms as fodder. In: B. B. Singh, D. R. Mohan Raj, K. Dashiell and L. E. N. Jackai (eds) Advances in Cowpea Research. Co-publication of International Institute of Tropical Agricultural Sciences and the JIRCAS, IITA, Ibadan, Nigeria; 313-325.

Valenzuela, H. and Smith, J. (2002). Cowpea. Sustainable agriculture, green manual crops, "College of tropical Agriculture and Human Resources" (CTAHR). 


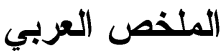

\section{تقييم التر اكيب الورراثيه من لوبيا العلف المنتخبه لمحصول العلف}

\author{
عبدالكريم سليمان محمد بذوى \\ قسم بحوث محاصيل العلف- معهد بحوث المحاصيل الحقليه-مركز البحوث الزر اعبه- مصر بلري
}

تم تقييم • 1 تز اكيب ور اثيه من لوبيا العلف (وتز اكيب منتخبه + صنف المقارنه) لمحصول العلــف و الــصفات

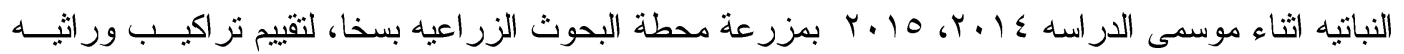
منتخبه للمحصول الاخضر العالى ومكوناته.

اوضحت البيانات وجود اختلافات عالية المعنويه ناتجه عن تأثير السنوات، الحشات و التراكيب الور اثثه، وكانت

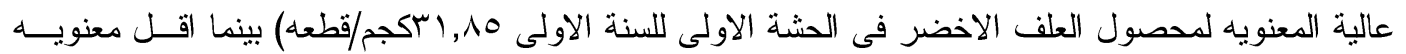
لمحصول العلف الاخضر فى الحشة الثانية للسنه الاولى.

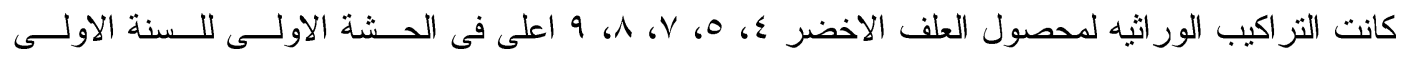

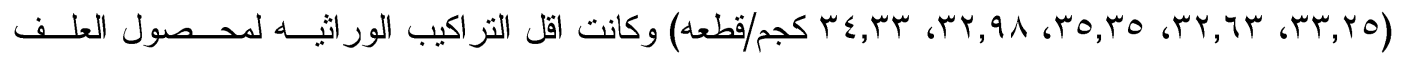

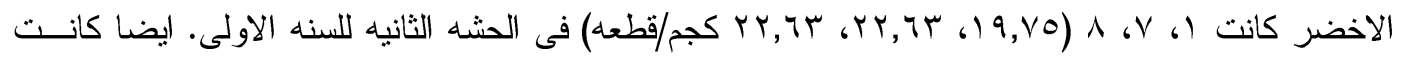

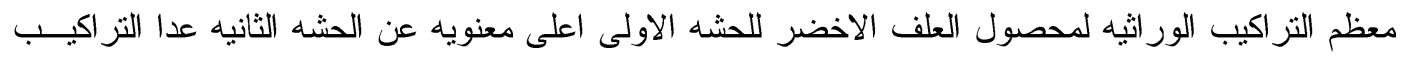

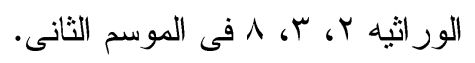

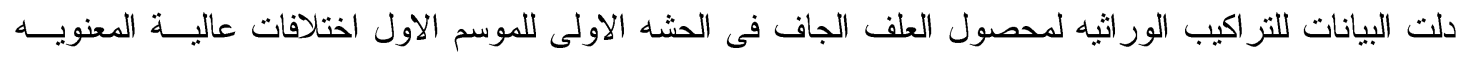

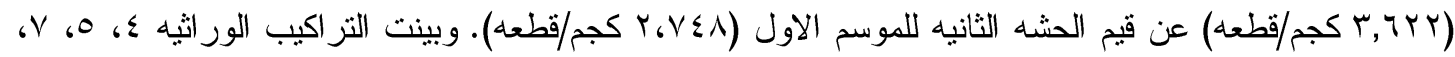

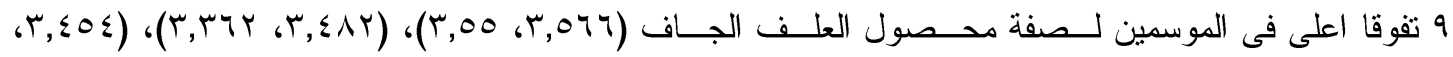
ب r

اظهرت نتائج نسبة ورق/سوق (على اساس الوزن الجاف) معنويه اقل فى الموسمين للحشه الاولى عن الحـشهـ

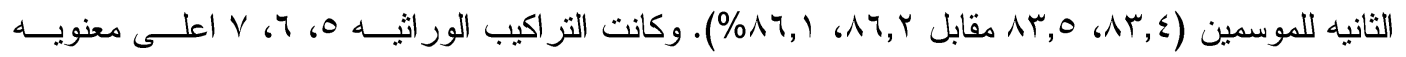

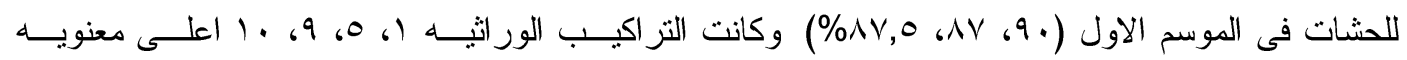

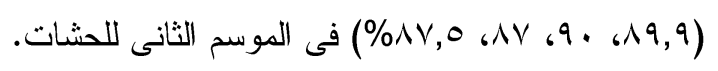

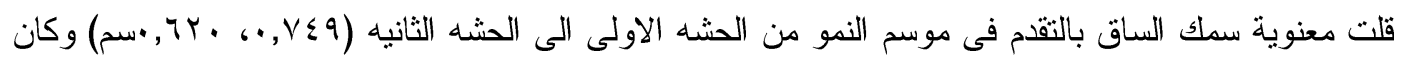

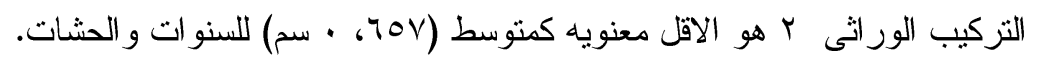

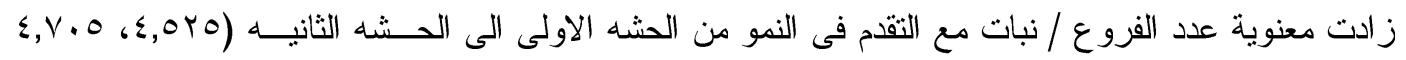

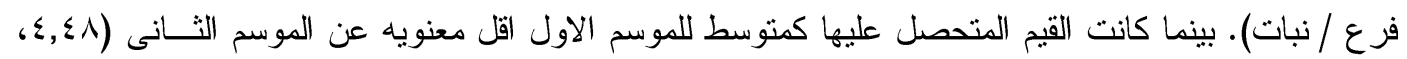
ه

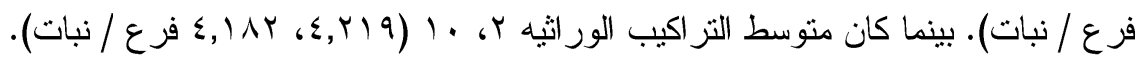

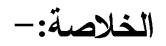

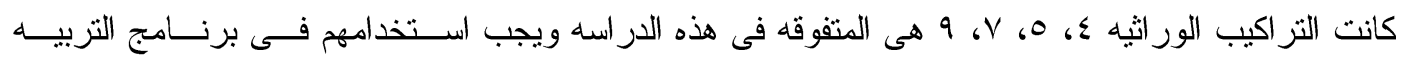
لمحصول العلف العالى. 